\title{
Correction to: Who is the ocean? Preface to the future seas 2030 special issue
}

\author{
Tero Mustonen • Kimberley H. Maxwell • Kaisu Mustonen • Russ Jones • \\ Halfdan Pedersen • Nuunoq (Per Ole Fredriksen) • Jamie Graham • \\ Dean Greeno - Suteji Hugu • Mibu Fischer • Eero Murtomäki
}

Published online: 7 May 2021

(C) Springer Nature Switzerland AG 2021

\section{Correction to: \\ Rev Fish Biol Fisheries \\ https://doi.org/10.1007/s11160-021-09655-x}

One of the affiliations of the author was incorrectly published in the original publication of the article. The

The original article can be found online at https://

doi.org/10.1007/s11160-021-09655-x.

T. Mustonen $(\bowtie) \cdot$ K. Mustonen · E. Murtomäki

Snowchange Cooperative, Selkie, Finland

e-mail: tero@lumi.fi

\section{K. H. Maxwell}

Whakatōhea, Te Whānau-a-Apanui, Ngāti Porou, Ngāti Tūwharetoa, Ngāitai, Environmental Research Institute, University of Waikato, Tauranga, New Zealand

R. Jones

Hereditary Chief, Haida Nation, Skidegate,

Haida Gwaii, Canada

H. Pedersen

Pikkoritta Consult, Aasiaat, Greenland

Nuunoq (Per Ole Fredriksen)

The Pisuna Project, Attu, Greenland

J. Graham

Institute for Marine and Antarctic Studies, University of Tasmania, Hobart, TAS, Australia correct affiliation of Russ Jones is "Hereditary Chief, Haida Nation, Skidegate, Haida Gwaii, Canada".

The original article has been corrected.

Publisher's Note Springer Nature remains neutral with regard to jurisdictional claims in published maps and institutional affiliations.

D. Greeno

College of Arts, Law and Education, University of

Tasmania, Launceston, TAS, Australia

D. Greeno $\cdot$ M. Fischer

Centre for Marine Socioecology, University of Tasmania,

Hobart, Australia

S. Hugu

TAO Foundation, Lanyu Island, Taiwan

M. Fischer

Oceans and Atmosphere, CSIRO, Brisbane,

QLD, Australia 